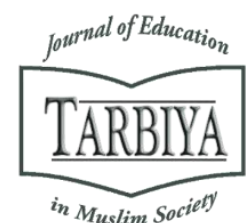

Available online at TARBIYA: Journal of Education in Muslim Society Website:

http://journal.uinjkt.ac.id/index.php/tarbiya

TARBIYA: Journal of Education in Muslim Society, 8(1), 2021, 57-65

\title{
STUDENTS' RESPONSES TO ADAPTED ONLINE TAHSIN QURAN LEARNING DURING THE COVID-19 PANDEMIC
}

\author{
Rifda Shabrina*, Uwes A. Chaeruman, Indina Tarjiah \\ State University of Jakarta, Indonesia \\ E-mail: shabrinarifda@gmail.com
}

Received: $27^{\text {th }}$ March 2021; Revised: $24^{\text {th }}$ May 2021; Accepted: $28^{\text {th }}$ June 2021

\begin{abstract}
Tahsin Quran is a method of learning to read the Quran that strives to increase the reader's ability to adhere to the guidelines established (tajwid). In tahsin Quran learning, teachers must pay close attention to students' letter pronunciation in the Quran, ideally face-to-face or in sync. However, the COVID-19 pandemic has necessitated online learning, requiring some alterations to its application. The purpose of this study was to determine how students respond to online Quran learning conducted virtually in one of South Tangerang's Quran learning facilities. Students are given questionnaires about instructor competencies, the substance of learning materials, and the efficiency of tahsin online learning, which are reinforced by an interview with one of the teachers, an institution member, and students. The results indicated that, based on student answers, the institution's implementation of tahsin Quran online learning has been highly successful, with some notes and inputs to consider to improve the quality of Quran online learning in the future.
\end{abstract}

Keywords: online learning; tahsin; Quran reading; COVID-19; online Quran learning

Abstrak

Tahsin Al-Qur'an merupakan pembelajaran membaca Al-Qur'an yang bertujuan untuk memperbaiki bacaan Al-Qur'an agar sesuai dengan kaidah (tajwid) yang ditetapkan. Dalam pembelajaran tahsin AlQur'an, guru atau instruktur perlu memperhatikan ketepatan tiap siswanya dalam melafalkan huruf dalam Al-Qur'an sehingga pembelajaran idealnya dilakukan secara tatap muka atau sinkron. Namun pandemi COVID-19 mengharuskan pembelajaran dilaksanakan secara daring sehingga membutuhkan beberapa penyesuaian dalam pelaksanaannya. Penelitian ini bertujuan untuk meneliti bagaimana respon siswa pembelajaran tahsin Al-Qur'an online yang dilaksanakan secara virtual di salah satu lembaga pembelajaran Al-Qur'an di Tangerang Selatan. Kuesioner mengenai kemampuan guru, isi materi pembelajaran, dan efektifitas pembelajaran tahsin yang dilaksanakan secara online diberikan kepada siswa yang kemudian hasilnya dilengkapi dengan hasil wawancara kepada salah satu guru, pihak lembaga, dan siswa. Hasil penelitian menunjukkan bahwa berdasarkan respon siswa pembelajaran tahsin Al-Qur'an online yang dilaksanakan di lembaga tersebut telah berjalan sangat baik dengan beberapa catatan dan masukan yang perlu diperhatikan untuk peningkatan kualitas pembelajaran tahsin Al-Qur'an daring yang akan datang.

Kata kunci: pembelajaran online; tahsin; membaca Al-Qur'an; COVID-19; belajar Al-Qur'an online

How to Cite: Shabrina, R., Chaeruman, U. A., Tarjiah, I. (2021). Students' Responses to Adapted Online Tahsin Quran Learning during the COVID-19 Pandemic. TARBIYA: Journal of Education in Muslim Society, 8(1), 57-65. doi:10.15408/tjems.v8i1.21715.

Permalink/DOI: http://dx.doi.org/10.15408/tjems.v8i1.21715

*Corresponding author

TARBIYA: Journal of Education in Muslim Society, p-ISSN: 2356-1416, e-ISSN: 2442-9848

This is an open access article under CC-BY-SA license (https://creativecommons.org/licenses/by-sa/4.0/) 


\section{Introduction}

Reading the Quran is an ability that must be mastered by every Muslim. In addition to reading, it is worth worship, the recitation of the Quran is also found in obligatory worship (such as prayer). Although the Quran is in Arabic, it has its own signs and guides that are different from reading ordinary Arabic text. So that every Muslim, even those who are good at Arabic, needs to learn how to read the Quran in order to read it properly and correctly following the reading of the recipient of the Quran, the Prophet Muhammad Saw.

Learning to read Quran in particular or in-depth is called tahsin Quran learning. Tahsin derives from Arabic which means to improve so tahsin Quran aims to improve the recitation of the Quran in order to read it in detail as God commands in sura Al-Muzammil verse 4. Tartil is not only reading the Quran slowly but also reading it eloquently (letters, words, and sentences) and in accordance with its tajwid (Fathoni, 2019). Therefore, the materials taught in tahsin learning are not only how to read hijaiyah letters, but also equipped with the tajwid guides.

In studying tahsin Quran, teachers or instructors need to pay attention to the accuracy of each student's reciting letters in the Quran so that the learning is ideally done face-to-face or in sync. However, with the COVID-19 pandemic occurring in 2020, face-to-face learning cannot be done due to government policy to carry out all activities from home and avoid crowds (Rasmitadila et al., 2020). So that the tahsin Quran learning also requires adjustment and innovation to be carried out even remotely. One form of innovation is by making it online. When it is implemented online, the learning strategies will be different. The difference in learning strategy can give different learning outcomes to students (Rohman et al., 2020). One of the strategies in Tahsin Al-Quran is blended learning that merged face-to-face and online learning. By implementing blended learning, the curriculum and other learning tools also need to be rearranged to match the synchronous and asynchronous models applied. The use of this strategy can maintain the commitment of participants through rewarding mechanisms also encourage collaboration of participants in the learning process, such as by reading the Quran together (Syaiful Romadhon et al., 2019). However, tahsin Al-Quran learning with a blended learning strategy cannot be implemented during the current COVID-19 pandemic because faceto-face learning has not been able to take place.

Based on these reasons and by adjusting the current situation, tahsin Quran learning should be implemented virtually. By doing it virtually, teachers can hear and watch the reading of the Quran directly at the same time. Teachers can also interact directly with students, give examples of appropriate reading, and correcting their Quran reading immediately. In addition, students can also interact directly with their friends so that learning does not feel rigid and boring.

This study aims to find out the response of participants of online Quran tahsin learning conducted virtually in three learning periods; October 2020, April 2021, and an additional class in Ramadan 2021 at one of the Quran learning institutions in South Tangerang. The results of this study will be used for the development of online Tahsin Al-Quran learning in the future, especially if implemented virtually. 


\section{Online Learning}

Online learning is learning integrated by computer technology and the internet. The application of online learning will be different from learning in ordinary classrooms so that the strategies and the objectives of learning also require changes and adjustments by the devices of educational institutions including teachers and parents of students (Rasmitadila et al., 2020). In online learning, students are required to learn more independently than as in usual classroom, so usually online learning is equipped with tasks that students must do. Assignments are the factors that contribute the most to students' performance in learning (Bravo-Agapito et al., 2021), though it should still need more attention when assigning it to students so that it is not too difficult and does not burden them. Support and interaction among students are also needed in this online learning because interactions between students can increase motivation to learn so that tasks can be completed properly (Beach, 2017). In addition to student interaction, student interaction with content and instructor interaction with students are also significant factors in student satisfaction with online learning (Alqurashi, 2019). Online learning has positive aspects such as cost and time effectiveness, safety, comfort, and increased participation from students. But there are also negative aspects that are often found like distractions and focus reduction, heavier workloads, problems with technology and the internet (signal), and also inadequate support from instructors and friends (Hussein et al., 2020).

Online learning can occur synchronously and asynchronously. Synchronous is when learning occurs at the same time so the media that can be used include chat, audio, and video conference (Hrastinski, 2006). While in asynchronous learning communication cannot take place at the same time so that media that can be used such as email, discussion forums, or using LMS in the delivery of learning material. Online learning in sync is widely done by educational institutions because in synchronous learning communication tends to increase when compared to asynchronous (Oztok et al., 2013). Based on the results of Offir et al.'s study also showed that students prefer to use synchronous learning compared to asynchronous. Synchronous learning allows students to be more interactive with teachers and other students. The more students are active in learning, the easier they are to understand the material and obtain good learning outcomes (Offir et al., 2008).

One of the many synchronous learning is virtual learning. Virtual learning can provide the same benefits as face-to-face learning as it is in sync at the same time (O'Flaherty \&Laws, 2014). The results of this study stated that students think they can feel a meaningful learning experience especially because they can interact directly with teachers and other students. Virtual learning also reduces their anxiety in learning or feeling isolated from the environment they usually experience when learning face-to-face. This learning also makes students easy to collaborate with other students. In a virtual learning environment, the characteristics of design (whether related to the information system or the learning content) must match and comply with the institution or stakeholders' requirements so that virtual learning can run successfully and can continue to be developed to improve user satisfaction and support the overall success learning (Mueller \&Strohmeier, 2011). Some of the criteria of virtual classes according to Jahn et al. include: (1) easy platform integration to other systems, interaction with existing LMS, respectively; (2) easy integration of new components; and (3) the configuration of the meeting room in such a way that a minimally adequate set of components can be provided (Jahn et al., 2012). 


\section{Tahsin Quran Learning}

Teachers have different strategies of teaching the Quran. These differences strategies can affect student's learning experience (Sai, 2018). From Sai's research, it is also known that memorization is the dominant point in the learning of the Quran. The majority of students only memorize verses without understanding the meaning and explanation of the verse. Many methods offer tahsin learning of the Quran and have been used in research, both tahsin learning for adults and children. Some of the methods of tahsin Al-Quran learning include Tilawati method, Tahsin Tilawah method, Iqra method, Qira'ati method, Baghdadiyah method, Ummi method, and so on (Mujahideen et al., 2020). In tahsin learning for elementary school children, Tilawati method can be used because it does not use too many theories that can burden children (Khoiruddin \&Kustiani, 2020). As for adult participants, tajwid theories can be taught more widely in their learning so they can use more complex methods such as At-tartil and Tsaqifa (Rahmawati; Rumainur, 2019).

Learning the Quran is usually done face-to-face, so when it is done online the learning strategy will be different. The difference in strategy can give different learning outcomes to students (Rohman et al., 2020). One of them is Hanafi et al. (Hanafi et al., 2019) who have developed an LMS to learning how to read the Quran called e-BBQ. Based on the research, it is known that the use of e-BBQ is considered effective in improving the ability to read the Quran compared to traditional methods. The instructors also think that e-BBQ makes it easier for them to administrate data. Blended learning strategies can also be used in Quran learning. Syaiful Romadhon et al. (2019) successfully created a blended learning strategy to learn tahsin Quran using social media that includes curriculum and material design, strategies to maintain participants' commitment through rewarding mechanisms, and encourage collaboration in the process, such as reading the Quran together.

\section{Method}

This study used a survey method to participants of tahsin Quran learning which was conducted virtually at Lembaga Tahsin dan Tahfizh Al-Qur'an (LTTQ) that located in East Ciputat, South Tangerang. Participants in this study were students who had participated in virtual tahsin learning during 16 meetings. The students in this learning consist of college students and general public aged 19 to 67 years old. Primary data was collected through the dissemination of questionnaires to 42 students while additional supporting data were obtained through interviews. Questionnaires are written in Google Form then distributed to each participant through the WhatsApp application. After spreading the Google Form links for two weeks, 11 Google Form fields were eligible for analysis.

The questionnaire contains 20 questions about participants' responses to tahsin Quran online learning. Questionnaires are analyzed using the Likert scale with the following interval score conditions:

- $0 \%-19.99 \%=$ Strongly disagreed $/$ Not good

- $20 \%-39.99 \%$ = Disagree / Less good

- $40 \%-59.99 \%$ = Sufficient $/$ Neutral 
- $60 \%-79.99 \%=$ Agree/ Good

- $80 \%-100 \%=$ Very agree/ Very good

The results were analyzed descriptively, then by combining it with the interview results conducted with three selected people from participants, one of the teachers, and the learning institution member.

\section{Results and Discussion}

This study analyzed students' perceptions about teachers' teaching ability in online learning, the learning materials, and the effectiveness of technology use in online learning. Here are the analysis of 11 questionnaires.

\section{Teacher Skills in Online Learning}

Based on the questionnaires that have been distributed to the students, it is known that the average ability of teachers in teaching tahsin Quran is $91.3 \%$ which means very good, as seen in Table 1.

Table 1. Students perception on teacher skills in tahsin Quran online learning

\begin{tabular}{llll}
\hline No. & Statements & $\begin{array}{l}\text { Result } \\
(\mathbf{\%})\end{array}$ & $\begin{array}{l}\text { Average } \\
\mathbf{( \% )}\end{array}$ \\
\hline 1a. & The teacher's voice can be heard clearly & 94.5 & 91.3 \\
& & 90.9 \\
\hline 1b. & the teacher delivers the lesson well and easily understood & 92.7 \\
\hline 1c. & $\begin{array}{l}\text { I get the opportunity to talaqqi or practice my reading directly in front of the } \\
\text { teacher in each learning session }\end{array}$ & \\
\hline 1d. & $\begin{array}{l}\text { I can easily interact, have discussions with friends or ask the teacher during the } \\
\text { lesson }\end{array}$ & 87.2 \\
\hline 1e. & I dare to practice my reading directly in front of friends and teacher \\
\hline 1f. & The class takes place conducively & 92.7 \\
\hline 1g. & The teacher corrects or gives feedback on my reading & 90.9 \\
\hline 1h. & The teachers can manage the learning time well & 96.3 \\
\hline
\end{tabular}

The results are also match with the student statements from the interviews. Teachers are very good at mastering learning materials and can deliver them well, even by online. In tahsin Quran learning, the interaction between teachers and students is an important component that must be implemented. Students are required to practice their reading directly in front of the teacher so that the teacher can correct and provide feedback on the reading of the Quran. Therefore, in learning tahsin Al-Quran online this must still be pursued as face-to-face learning. Based on statements number 1.c, 1.d, 1.e, and 1.g, it is known that teachers can build such interactions in online classrooms so that students can be brave and comfortable to practice their reading. The findings are also consistent with the result from O' Flaherty and Laws' study (2014) which stated that meaningful learning experiences can be felt by students who learn online if there is a direct interaction with teachers and other students in online learning.

One of the techniques that teachers do to improve interaction in online learning is to ask questions which is also found by Hrastinski et al. in the results of his research (Hrastinski et al., 2019). In this tahsin Quran online learning students are also allowed to ask questions, especially 
on lessons that are not yet understood. But based on the interview results, teachers find it somehow more difficult to explain the answers to students when learning online, because they are more time-consuming and the answers cannot be explained directly such as when learning tahsin face-to-face. Therefore, more online teaching experience is still needed for the teachers to be more competent in addressing the problems of online tahsin learning.

\section{Learning Material}

In addition to assessing the content of the learning materials, this questionnaire also identifies whether the learning materials are easily accessible or obtained by students online. Overall, online tahsin Quran learning materials reached an average result of 89.8\% which means that the content of the learning material has been superfine. The learning material covers the whole theory and practice of tajwid science that is delivered solidly and clearly, as seen in Table 2.

Table 2. Students' perception on learning material in tahsin quran online learning

\begin{tabular}{llll}
\hline No. & Statements & Result (\%) & Average (\%) \\
\hline 2a. & The lessons that explained can be well understood & 92.7 \\
\hline 2b. & The lessons that explained are easy to replicate or practice & 96.8 \\
\hline 2c. & Student can stay focused on the lesson & 96.3 \\
\hline 2d. & The lesson materials are given or being able to be downloaded every day & 76.3 \\
\hline 2e. & The lessons can be recorded by the students & 87.2 \\
\hline
\end{tabular}

Statements no. $2 \mathrm{~d}$ and $2 \mathrm{e}$, regarding the ease of access to learning materials, had lower results than other statements in the learning materials $(76.3 \%$ and $87.2 \%)$ even though both are in good category. According to the interview results with students, it is because not all the students feel that the learning materials can be downloaded, recorded, or given every day during online learning, so they find it hard to repeat the lesson at home. However, other students state that the learning recordings have been uploaded and can be downloaded easily by them. This dissent can be caused by a lack of instruction and communication from teachers or learning institutions. To overcome this problem, teachers or organizing institutions can create discipline and learning plans to reduce the obstacles that can occur during online learning.

\section{The Effectiveness of Learning Tahsin Quran Online}

In Table.3, it is known that the effectiveness of learning tahsin Quran online gets excellent results $(81.2 \%)$, although not as high as the results obtained in the two components measured earlier, as seen in Table 3 .

Table 3. Students perception on the effectiveness of learning tahsin Quran online

\begin{tabular}{llll}
\hline No. & Statements & $\begin{array}{l}\text { Result } \\
\mathbf{( \% )}\end{array}$ & $\begin{array}{l}\text { Average } \\
\text { (\%) }\end{array}$ \\
\hline 3a. & The lesson always takes place on time & 83.6 \\
\hline 3b. & $\begin{array}{l}\text { The online learning runs smoothly, not hampered by signals/networks or other } \\
\text { technical matters }\end{array}$ & 74.5 \\
\hline 3c. & The given online learning link (zoom or google meet) can be accessed easily & 83.6 \\
\hline 3d. & I think this online learning makes me easier to learn Tahsin Al-Quran & 90.9 \\
\hline 3e. & The learning committees and teachers have facilitated learning well & 94.5 \\
\hline 3f. & This online learning is more effective than face-to-face as usual & 56.3 \\
\hline 3g. & I am willing to join the next online Tahsin Al-Quran learning & 85.4 \\
\hline
\end{tabular}


Based on statement $3 \mathrm{~b}$ and the interview results with students and teachers, it is known that learning is hampered several times by signal interference. The differences in signal strength in various places cause this to be one of the risks that online learning will experience, as stated by Hussein et al. in his research (Hussein et al., 2020).

Then based on statements number $3 \mathrm{~d}, 3 \mathrm{e}$, and $3 \mathrm{f}$, although teachers and learning institutions have facilitated this online learning well and students feel this makes it easier for them to learn tahsin Quran, but the level of effectiveness, when compared to face-to-face tahsin learning, is only $56.3 \%$. This is because some students still feel more comfortable if their reading of the Quran is listened and corrected directly by teacher. In addition, students also hope that with the implementation of tahsin Quran online, the learning time applied can be more flexible so that students will not lose their chance to study if it clashes with their other activities. These time problems can be solved if online learning is implemented asynchronously, such as using LMS or groups on social media. Although in asynchronous learning the interaction of teachers and students cannot take place as it did when learning was in sync (Oztok et al., 2013).

\section{Conclusion}

Tahsin Quran online learning organized by Quran learning institute in East Ciputat has been running very well according to the student's response, in terms of the teacher's ability to teach, the learning materials, and also its effectiveness. However, some suggestions for improving online learning in the future can also be applied to other online learning such as ease of access to learning materials, more intense interaction between teachers and students, and flexibility of learning time. Students and teachers also still need adjustments in the implementation of this online learning so that it is expected that in the next online learning, technical-related obstacles can be reduced.

\section{References}

Alqurashi, E. (2019). Predicting student satisfaction and perceived learning within online learning environments. Distance Education, 40(1), 133-148. https://doi.org/10.1080/01587919.2018.1553562

Beach, P. (2017). Self-directed online learning: A theoretical model for understanding elementary teachers' online learning experiences. Teaching and Teacher Education, 61, 60-72. https://doi.org/10.1016/j.tate.2016.10.007

Bravo-Agapito, J., Romero, S. J., \& Pamplona, S. (2021). Early prediction of undergraduate Student's academic performance in completely online learning: A five-year study. Computers in Human Behavior, 115, 106595. https://doi.org/10.1016/j.chb.2020.106591

Fathoni. A. (2019). Metode Maisura: Petunjuk Praktis Tahsin Tartil Al-Quran. Tangerang Selatan: Yayasan Bengkel Metode Maisura 
Hanafi, Y., Murtadho, N., Ikhsan, M. A., Diyana, T. N., \& Sultoni, A. (2019). Student's and instructor's perception toward the effectiveness of E-BBQ enhances Al-Quran reading ability. International Journal of Instruction, 12(3), 51-68. https://doi.org/10.29333/iji.2019.1234a

Hrastinski, S. (2006). Introducing an informal synchronous medium in a distance learning course: How is participation affected? Internet and Higher Education, 9(2), 117-131. https://doi.org/10.1016/j.iheduc.2006.03.006

Hrastinski, S., Stenbom, S., Benjaminsson, S., \& Jansson, M. (2019). Identifying and exploring the effects of different types of tutor questions in individual online synchronous tutoring in mathematics. Interactive Learning Environments, 0(0), 1-13. https://doi.org/10.1080/10494820.2019.1583674

Hussein, E., Daoud, S., Alrabaiah, H., \& Badawi, R. (2020). Exploring undergraduate students' attitudes towards emergency online learning during COVID-19: A case from the UAE. $\begin{array}{lllll}\text { Children and Youth } & \text { Services Review, 119, }\end{array}$ https://doi.org/10.1016/j.childyouth.2020.105699

Jahn, M., Piesche, C., \& Jablonski, S. (2012). Flexibility requirements concerning the design of synchronous e-learning systems. Interactive Technology and Smart Education, 9(4), 233245. https://doi.org/10.1108/17415651211284020

Khoiruddin, H., \& Kustiani, A. W. (2020). Manajemen Pembelajaran Tahsin Al-Quran Berbasis Metode Tilawati. Jurnal Isema: Islamic Educational Management, 5(1), 55-68. https://doi.org/10.15575/isema.v5i1.5546

Mueller, D., \& Strohmeier, S. (2011). Design characteristics of virtual learning environments: State of research. Computers and Education, 57(4), 2505-2516. https://doi.org/10.1016/j.compedu.2011.06.017

Mujahidin, E., Daudin, A., Nurkholis, I. I., \& Ismail, W. (2020). Tahsin Al-Quran untuk dewasa dalam perspektif Islam. Jurnal Pendidikan Luar Sekolah, 14(1), 26. https://doi.org/10.32832/jpls.v14i1.3216

O'Flaherty, J. A., \& Laws, T. A. (2014). Nursing student's evaluation of a virtual classroom experience in support of their learning bioscience. Nurse Education in Practice, 14(6), 654-659. https://doi.org/10.1016/j.nepr.2014.07.004

Offir, B., Lev, Y., \& Bezalel, R. (2008). Surface and deep learning processes in distance education: Synchronous versus asynchronous systems. Computers and Education, 51(3), 1172-1183. https://doi.org/10.1016/j.compedu.2007.10.009

Oztok, M., Zingaro, D., Brett, C., \& Hewitt, J. (2013). Exploring asynchronous and synchronous tool use in online courses. Computers and Education, 60(1), 87-94. https://doi.org/10.1016/j.compedu.2012.08.007

Rahmawati, D. (2019). Penerapan Metode Tsaqifa Dengan Metode Kooperatif Pada Pengajaran Baca Al-Quran Kelompok Pengajian Muslimah Dusun Pokoh Desa Wonoboyo Kecamatan Wonogiri Kabupaten Wonogiri. EVALUASI: Jurnal Manajemen Pendidikan, 3(May), 1-9. 
Rasmitadila, Aliyyah, R. R., Rachmadtullah, R., Samsudin, A., Syaodih, E., Nurtanto, M., \& Tambunan, A. R. S. (2020). The perceptions of primary school teachers of online learning during the covid-19 pandemic period: A case study in Indonesia. Journal of Ethnic and Cultural Studies, 7(2), 90-109. https://doi.org/10.29333/ejecs/388

Rohman, B., Aziz, J. A., Imran, A., \& Jarudin, J. (2020). Distance Instructional Strategies and Learning Motivation towards Learning Outcome of the Study Al-Quran in Situation a COVID-19 Pandemic. Universal Journal of Educational Research, 8(12), 6609-6619. https://doi.org/10.13189/ujer.2020.081225

Rumainur, R. (2019). Efektivitas Metode at-Tartil dalam Pembelajaran Tahsin al-Quran Mahasiswa Perguruan Tinggi Keagamaan Islam di Kalimantan Timur. Fenomena, 11(1), 1-10. https://doi.org/10.21093/fj.v11i1.1403

Sai, Y. (2018). Teaching Quran in Irish Muslim schools-curriculum, approaches, perspectives and implications. British Journal of Religious Education, 40(2), 148-157. https://doi.org/10.1080/01416200.2016.1269723

Syaiful Romadhon, M., Rahmah, A., \& Wirani, Y. (2019). Blended learning system using social media for college student: A case of tahsin education. Procedia Computer Science, 161, 160-167. https://doi.org/10.1016/j.procs.2019.11.111 